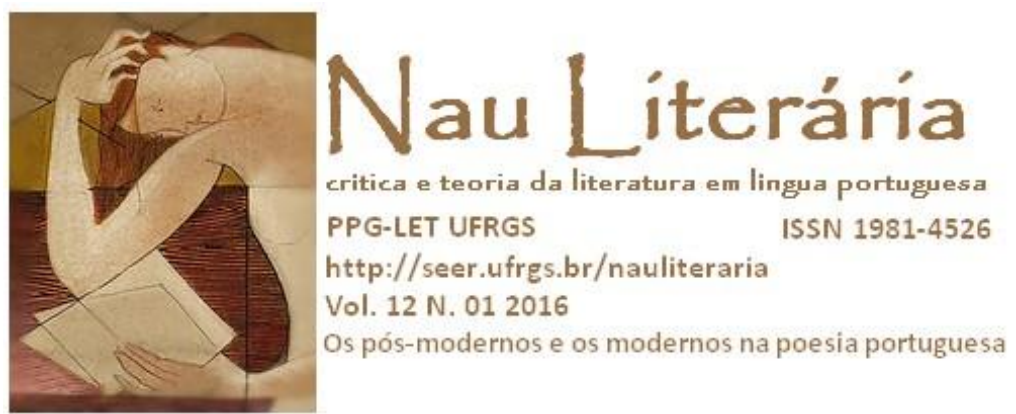

\title{
AL BERTO: UM PÉRIPLO PELO SENTIR
}

\section{AL BERTO: CIRCUMNAVIGATING FEELINGS}

\author{
Camila Emanuele Martins de Souza ${ }^{1}$
}

\begin{abstract}
Resumo: Este artigo objetiva estudar, sob a perspectiva da melancolia, os livros Salsugem (1984) e Horto de Incêndio (2010), de Al Berto. A partir da análise dos poemas, pesquisa-se de que forma o discurso melancólico é agenciado, na poética albertiana, e de que maneira ele se relaciona com questões como o corpo, a memória, a escrita e o tempo.
\end{abstract}

Palavras-chave: Salsugem; Horto de Incêndio; Melancolia; Poesia Portuguesa.

Abstract: This paper aims, from the point of view of melancholy, to study the books Salsugem (1984) and Horto de Incêndio (2010), by Al Berto. From the analyses of the poems, it searches how the melancholic speech is handled in Al Berto's poetic and how that melancholy is related to body, memory, writing and time.

Keywords: Salsugem; Horto de Incêndio; Melancholy; Portuguese Poetry.

Alberto Raposo Pidwell Tavares, que se assinava Al Berto, nascido em Coimbra, na data de 1948, residiu, nessa cidade, por um curto período e ainda criança mudou-se para Sines juntamente com sua família. Antes da publicação de seu primeiro livro literário, exercia atividades relacionadas à pintura. Em 1967, ele se estabelece em Bruxelas para cursar artes plásticas na École Nationale Supérieure d'Architecture et des Arts Visuels. O artista português não completou o curso e a partir daí iniciou suas errâncias; o jovem português percorreu o território europeu, incursionando pelo universo underground da década de 70. Bélgica, França e Espanha compuseram as experiências andarilhas de Al Berto. Nessa época, ele publica o livro pictórico Projeto 69 (1970), que reúne desenhos, juntamente a textos escritos em francês e inglês.

Al Berto iniciou sua trajetória de poeta em língua portuguesa no ano de 1977 com a publicação de À procura do vento num jardim d'agosto (1977), livro que hibridiza prosa e poesia, e tematiza o homoerotismo, as drogas, o espaço urbano e a angústia. Nos livros

\footnotetext{
${ }^{1}$ Mestre em Estudos Literários (UFRGS)
} 
seguintes, esses assuntos tornam-se a assinatura poética albertiana. Salsugem, publicado em 1984, mergulha na conjuntura do viajante errante que se lança em uma jornada pelo mar e pelas cidades. Horto de incêndio, publicado em 1997, é o último livro de Al Berto e remete, com sua titulação, ao Horto das Oliveiras, onde Jesus percorreu sua via crucis. Nos poemas, as imagens que se perfilam são a de corpos despedaçados que traçam seus caminhos pela degeneração e em direção a ela.

Ao percorrer os poemas de Salsugem e de Horto de incêndio, o leitor se depara com um universo que gravita em torno: do deserto, do mar, do marinheiro, do sal, das embarcações, do crepúsculo, do corpo, da casa, da cidade, do incêndio e da escrita. Toda essa imagética transporta para o que Manuel Frias Martins (1986) denomina de eidos do desassossego. Essa melancolia que atravessa a poesia de Al Berto é o discurso que reavalia o sujeito, a própria poesia e o mundo. Memória, nostalgia, escrita e melancolia coincidem na poética do referido escritor:

\begin{abstract}
Mas retomemos os poetas que ocupavam a nossa atenção para afirmar que um dos autores citados (Al Berto) não se esgota no eidos de um desassossego exacerbado ou numa qualquer rebeldia (aparentemente) sem constrangimentos. Se em Trabalhos do Olhar Al Berto sugeria a sua poesia por uma apurada convicção estética da lógica do seu próprio desassossego, em Salsugem encontramos o seu aprofundamento artístico no sentido da representação se uma melancolia que fascinantemente se apropria de si mesma e do mundo; uma melancolia que no quadro da poética mais recente, sustenta uma das mais lúcidas estratégias de reavaliação da composição poética (MARTINS, 1986, p. 121).
\end{abstract}

A consciência da escrita é uma marca dessa poética, que não se esquece da melancolia para reexaminar a realidade. Mas o que essa melancolia discursiva de Al Berto pode dizer sobre a contemporaneidade? A contemporaneidade de Al Berto está em seu incômodo diante do seu presente. A angústia, o desespero, a tristeza e a marginalidade são maneiras de expressar esse incômodo, essa forma de resistência perante as incertezas do mundo.

O texto, O que é contemporâneo (2009), de Giorgio Agamben, aborda a ideia de que a compreensão do contemporâneo pode estar vinculada à noção de anacronismo. É interessante esse pensamento, porque ele vincula o passado ao contemporâneo, que pode ser entendido, portanto, como "uma singular relação com o próprio tempo, que adere a este e, ao mesmo tempo, dele toma distância" (AGAMBEN, 2009, p. 59). Nessa convivência de desajustamento com seu tempo, o contemporâneo, de acordo com o filósofo, é capaz de vislumbrar a obscuridade na luz, ou seja, ele consegue antever a obscuridade que está implicada em sua época: "contemporâneo é aquele que recebe em pleno rosto o facho de trevas que provém de seu tempo" (AGAMBEN, 2009, p. 64).

A degradação das cidades, a mercantilização das pessoas, "os dias sujos” podem ser vistos, nessa poesia, sob a perspectiva de quem consegue ver as trevas em sua atualidade. 
Além de ser uma poesia que problematiza questões comuns ao tempo atual e ser cronologicamente próxima ao "hoje", a poética albertiana possui essa relação de afastamento e aproximação com a atualidade.

Essa dinâmica de afastamentos e aproximações, em relação à realidade, faz a poesia do poeta português não se esquivar de preocupações como a passagem do tempo. $\mathrm{O}$ transcorrer temporal imprime no ser humano a consciência da proximidade da morte e do esgotar da vida, que são duas questões presentes em Salsugem e Horto de incêndio ${ }^{2}$. O eu lírico, nesses livros, depara-se com a precariedade da vida e com a sua finitude. Ao defrontarse com as memórias das experiências passadas, com os amores perdidos, com a juventude e a infância já inacessíveis, o eu poético admite sua derrota diante da temporalidade.

$\mathrm{Na}$ última estrofe do poema a seguir, de "Cinco fotografias para Alexandre da Macedónia", a solidão e as "fotografias" são as realidades que restam ao eu poético:

hoje fico só

cismo ao reparar nestas fotografias amarelecidas

o sol ainda escuta teu rosto

enquanto o olhar vai sorvendo

a parda melancolia das conchas (SGM in MD, p. 287)

O "hoje" presentifica o fim irremediável do indivíduo, do qual resta a memória do outro. A memória-fotografia, como a vida do eu lírico, sofre a deterioração temporal.

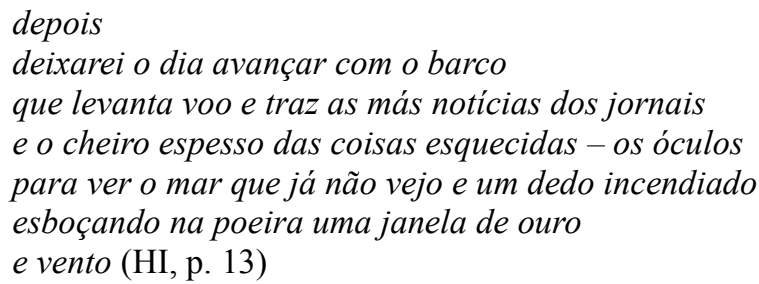

Nesse trecho do poema "Outro dia", constata-se também a marcação enfática do advérbio. Nesse caso, o "depois" isolado no verso aponta para sua importância e relevância na última estrofe do poema. O "depois" localiza o leitor nessa posterioridade; aquilo que sucedeu a todos os acontecimentos. Após o transcorrer da vida, o sujeito está próximo ao término de sua existência, "o cheiro espesso das coisas esquecidas", "os óculos para ver o mar que já não vejo" e o "dedo incendiado" demonstram a ruína do indivíduo, que, dominado pela senilidade e com as marcas de incêndio, permite ao "dia avançar" sem resistência. A ausência de reação contra o tempo não é apenas conformismo, mas sim a consciência na nulidade de opor-se ao

\footnotetext{
${ }^{2}$ As referências bibliográficas dos trechos de Salsugem e de Horto de Incêndio serão feitas, ao longo do artigo, da seguinte maneira, respectivamente: SGM in MD; e HI. As abreviações correspondem a: SGM - Salsugem, HI - Horto de Incêndio e MD - Medo. Sendo MD, O medo: trabalho poético 1974-1997, antologia poética de Al Berto que foi utilizada, nesse artigo, para analisar os poemas de Salsugem.
} 
devir.

A ótica de destruição confere à poética albertiana o olhar melancólico que testemunha o definhar dos seres. No poema "III de Morte de Rimbaud", revela-se: "mas a morte, quando se aproxima, é uma coisa simples... vem comer à mão a cinza melodiosa dos dias" (HI, p. 69). O sujeito parece aceitar a dinâmica temporal, contudo dirime a dor e a angústia que o acompanham: "é uma coisa simples". No início do poema, há a enumeração de fragmentos da memória e do cotidiano do eu poético a partir do viés negativo. Essa enumeração pode significar a tentativa de ordenar os fatos dolorosos que circundam o sujeito, porque o que é rememorado, nessa parte, é aquilo que causa sofrimento a ele e a Rimbaud.

\section{Os dias estão cheios de cartas e de recomendações, de amigos que partem para sempre, ou adoecem, de recados e de intrigas, de contas intermináveis, de ouros, de corpos, de fortuna e de infortúnios de morte, e de cães feridos a uivar à porta da desolação (HI, p. 69).}

O temor do tempo reverbera o sentimento de melancolia no texto. $\mathrm{O}$ olhar de frente para a morte causa, no eu, a reflexão negativa sobre os fatos que acontecem a sua volta. É interessante citar, sobre a dramaticidade do tempo, as palavras de Jaime Ginzburg, no ensaio "Literatura brasileira: autoritarismo, violência, melancolia", inserido no livro Crítica em tempos de violência: "A percepção do tempo, para pensar com Scliar, é pautada por melancolia. É um tempo não superado, a voz da enunciação se resolve em um presente esfacelado pelo peso de um passado que não pôde ser inteiramente compreendido ou assimilado. A melancolia se articula com o trauma". (GINZBURG, 2012, p. 182). Nessa poética, o tempo é pestilento, o sujeito, ao olhar para o pretérito, percebe ação deletéria do tempo sobre o presente. Passado, presente e futuro relacionam-se, tensionando o indivíduo em direção à fragmentação. O trauma ocorre pela impossibilidade da conciliação com o tempo, determinando a caída na melancolia. À consciência da vinculação entre tempo e morte, adiciona-se um terceiro termo: doença, que proporciona ao indivíduo o vislumbre quase material da morte. Acometido pela morbidade, o sujeito doente pode aguçar sua lucidez diante da realidade.

Em Al Berto, sobretudo, em Horto de incêndio, a doença imprime a marca indelével do thánatos. No trecho do poema intitulado "sida", é possível deparar-se com o transtorno provocado pela enfermidade no eu poético:

e mais nada se move na centrifugação

dos segundos - tudo nos falta

nem a vida nem o que dela resta nos consola

a ausência fulgura na aurora das manhãs

e com o rosto ainda sujo de sono ouvimos 
o rumor do corpo a encher-se de mágoa (HI, p. 36)

A doença confere ao indivíduo a percepção aguda do tempo, de tal forma que na passagem dos segundos "mais nada se move". Aqui, pode-se entrever a interiorização do sujeito, discutida por Agamben, em Estâncias: a palavra e o fantasma na cultura ocidental, em que o estado acidioso leva ao isolamento do indivíduo em si (2007, p. 30). O mundo e o sujeito confundem-se, o indivíduo enlutado do poema, por influência de uma causa externa, volta-se para si. Assim, um luto real impõe-se ao eu lírico, a morte dos que

\author{
têm nome e nos telefonam \\ um dia emagrecem - partem \\ deixam-nos dobrados ao abandono \\ no interior duma dor inútil muda \\ e voraz (HI, p. 36)
}

Em Origem do drama trágico alemão, Walter Benjamin disserta sobre essa relação íntima que se estabelece entre a pessoa e o objeto do luto:

De fato, enquanto que no domínio afetivo não raras vezes a atração e a estranheza alternam na relação de uma intenção com o seu objeto, o luto é capaz de uma muito especial intensificação e de um aprofundamento continuado da sua intenção. A meditação profunda (Tiesfsinn) é sobretudo própria de quem é triste. (BENJAMIN, 2011, p. 145)

“A dor inútil muda e voraz" e a ausência que "fulgura na aurora das manhãs" são resultados dessa "intensificação" e "aprofundamento" que se realizam entre indivíduo e o que se perdeu.

Além do luto concreto pelos que foram vítimas do vírus da AIDS, pode-se ler, no poema, o luto pelo objeto inapreensível. "Sida" agencia o luto do eu poético pela sua incapacidade de apreender a realidade, que desmorona diante dele: "nem a vida nem o que dela resta nos consola". Deste modo, a melancolia do eu poético refere-se não somente à morte efetiva de uma pessoa, mas, também, à perda de um objeto que ele de fato não possui, já que o bem lhe é inacessível. De acordo com Agamben, mesmo não possuindo o objeto, o indivíduo empreende a operação psicológica de antecipar a perda daquilo que ainda não é seu. Inaugura-se, portanto, as seguintes relações entre o sujeito e o objeto: perda e apropriação, afirmação e negação, presença e ausência. A teoria freudiana afirma que o sujeito enlutado, por não resolver a sua "perda", recolhe-se em si mesmo. Assim, complementa o filósofo, o melancólico possui uma vinculação de fidelidade com o objeto, por meio do ambivalente binômio ausência-presença. Sobre isso, esclarece Agamben:

Cobrindo o seu objeto com os enfeites fúnebres do luto, a melancolia lhes confere a fantasmagórica realidade do perdido; mas enquanto ela é o luto por um objeto inapreensível, a sua estratégia abre um espaço à existência do irreal e delimita um cenário em que o eu pode entrar em relação com ele, 
tentando uma apropriação que posse alguma poderia igualar e perda alguma poderia ameaçar. (AGAMBEN, 2007, p. 45)

Conforme essa perspectiva, o desespero do melancólico é resultado do conflito entre o indivíduo e o desejo do bem perdido. Além disso, o caráter dual de ausência e presença do objeto tem a propriedade de produzir ainda mais dor e desespero.

Diante da impossibilidade de resolver os problemas do mundo, na poética albertiana, o eu é invadido pela melancolia. Assim, o desejo de "limpar o mundo" esbarra na inexequibilidade; essa impossibilidade de expurgar a "sujeira" que contamina a realidade impregna de melancolia a poesia de Al Berto:

que o dia te seja limpo
e para lá da pele constrói o arco de sal
a morada eterna - o mar por onde fugirá
o etéreo visitante desta noite (HI, p. 9-10)

O eu poético guarda o anseio de fundar um cosmos, no qual os dias passassem mais lentos e fossem mais limpos. A melancolia, aqui, é expressa pela inquietude em relação ao tempo. Observa-se, no trecho subsequente do poema de Salsugem, o desconforto ante o devir:

\author{
Espero o cortante sal-gema das ilhas... a ilusão \\ de me prolongar na secreta noite dos peixes \\ adormeço \\ para que estes dias aconteçam mais lentos \\ nas proximidades inalteráveis deste mar (SGM in MD, p. 270)
}

Retomando a questão dos "dias limpos", é possível notar que em outros poemas de Salsugem e Horto de incêndio o desejo de "limpeza" é substituído por uma conjuntura de contaminação, de perversão e de deterioração:

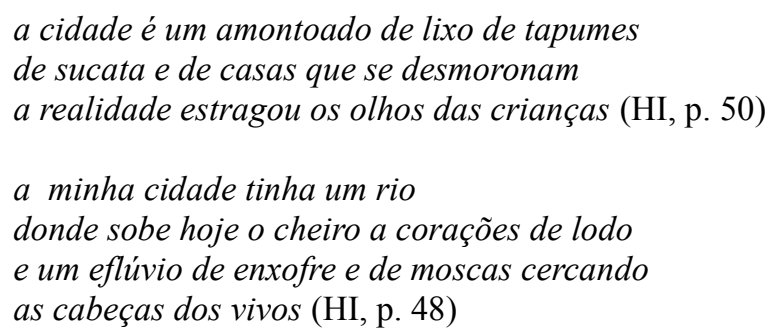

Nesses excertos do poema “carta de Émile”, não há espaço para os desejos utópicos: as caracterizações da cidade enfatizam a negatividade e a distopia. Esses versos não permitem ao leitor desprender-se do discurso de decadência e de ruína: "tudo se decompõe / apodrece / e as mãos enterram-se no estrume das horas - assim / te escrevo / sentado na parte mais triste do meu corpo" (HI, p. 49).

No cenário de degradação, observa-se a preocupação com a juventude. Os tempos de 
outrora, nos quais os excessos eram dominantes, são lembrados com nostalgia. A velhice, o tempo de enunciação dos poemas, é aquele em que a ruína se impõe. A juventude evidencia como o sujeito está submetido a uma realidade sem escolhas nem soluções plausíveis.

O modo condicional é uma das formas em que a poética de Al Berto demonstra o desejo de reviver os fatos do pretérito. A impossibilidade está impregnada no indivíduo, que tem consciência dos obstáculos interpostos à possibilidade de retorno dos seus amigos queridos e do amor improvável. No poema de Salsugem, o eu poético conjectura:

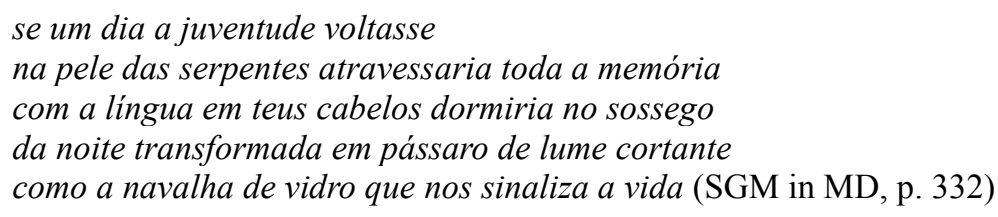

O "se" não é concretizado, está fadado ao fracasso e à inviabilidade, o sujeito já cansado não tem ilusões nem idílios onde habitar. Na última estrofe desse mesmo poema, depois de percorrer as possibilidades incluídas na ilusória volta da juventude, o retorno à realidade é mais forte:

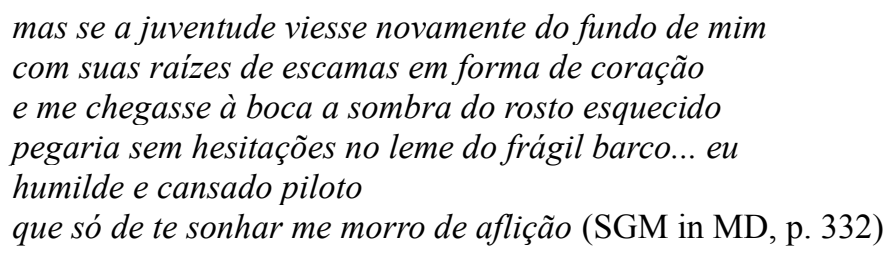

Entretanto, essa poesia é pautada pelo agenciamento de contradições e, como tal, é necessário ponderar a característica indicada da ausência de crença no futuro. Os versos envoltos pela morte e pela desesperança - "etéreo / entram com vagar na cidade desmoronada / na fissura deste tempo pestífero / que já não lhes pertence” (HI, p. 27) e "e morres / carregado de tristezas e de mistérios - morres / algures / sentado numa praceta de bairro - o olhar fixo / no inferno marítimo das aves" (HI, p. 42) - são contrapostos pelo vislumbre do paraíso, de outra terra onde o sujeito possa fixar morada.

O passado é o ponto a partir do qual a poética albertiana observa o entorno e suas memórias. É Orfeu que, ao olhar para trás, a fim de certificar-se se Eurídice está no seu encalço, se distancia dela. A relação entre objeto e sujeito é de distanciamento e de desejo interdito. O paraíso está irremediavelmente perdido, direcionando a poética de Al Berto para a melancolia de luto e de impossibilidade.

É impossível passar despercebido, nas leituras dos poemas, como estão interligados o tempo, a memória e o corpo. A poesia albertiana está situada nos espaços da memória e do 
corpo, nos quais o eu poético constrói e ressignifica o passado, o sujeito e a palavra. O corpo, sobretudo, é o topos a partir do qual a poética de Al Berto se relaciona com as outras questões que gravitam na obra. Em uma entrevista gravada pela emissora de televisão RTP (Rádio e Televisão de Portugal) ${ }^{3}$, o escritor fala sobre a importância da corporeidade na sua obra:

Acho que faço parte de uma linhagem de poetas, e não tenho qualquer arrogância, mas também não tenho humildade em dizê-lo, nem uma coisa nem outra, digo isto porque é assim, eu assumo isso e sempre o fiz; eu acho que pertenço a uma linhagem de poetas que a escrita passa pelo corpo, se assim se pode dizer, isto é, não há escrita sem motivações, sem viver em geral e sem que haja coisas que perturbem, a escrita vem de uma perturbação. (Entrevista, Al Berto)

As motivações, o sentir, a vida e a perturbação são apresentadas, no discurso do poeta português, como elementos em torno dos quais sua poética se constrói. Contudo, o corpo, que se relaciona às experiências e que não está indiferente às provocações impostas pelo entorno, não pode ser configurado por uma imagem de centralidade. Porque o corpo-palavra, o corpooutro, o corpo narcísico, o corpo fragmentado fundam essa poesia pelo estilhaçamento da centralização, seja do sujeito, seja dos rótulos.

Sobre essa última questão, é interessante resgatar o ensaio de Sasaki "A intimidade penumbrosa": nota sobre a escrita de si em Al Berto",em que ele afirma a capacidade de Al Berto, tanto de rechaçar, quanto de aceitar para si todas as denominações que se relacionam a sua poesia:

Seria desnecessário apontar este ou aquele crítico que referende tais adjetivos, já que não há "rótulo", entre esses, que não esteja assentado pela recepção crítica de Al Berto. E acrescentaríamos: não há rótulo que o próprio $\mathrm{Al}$ Berto não aceite e, em certa medida, não reclame para sua obra - seja por meio de entrevistas, seja por meio do próprio texto literário. Para determo-nos apenas nas entrevistas, que são mais pontuais, citamos as afirmações: no Diário de Notícias: "[O narcisismo] existe, mas não sei se da forma como analisaram" e, mais adiante, quando questionado se assumia o confessionalismo, "Sim, mesmo que seja um tique de geração" (AL BERTO, 1997b, p. 32); e, na Ler: "A primeira referência, para qualquer coisa que se escreve, é biográfica" (AL BERTO, 1989b, p. 13). (SASAKI, 2013, p. 158)

As entrevistas citadas, nesse excerto, demonstram que o poeta compreende a abrangência das possibilidades de classificação dos seus livros, como também entende os reducionismos dessas etiquetas. Como afirma o escritor, sua produção está intimamente conectada ao biográfico. Ao apontar a vida como referência, Al Berto não afirma a existência de coincidências simétricas entre o biográfico e seus livros. O que ele indica são as zonas de contato existentes entre a literatura e o real. Al Berto e Alberto Pidwell Tavares são dimensões que se enlaçam, em que realidade e ficção se influenciam e se transformam, tornando-se difícil determinar em que momento cada uma inicia.

\footnotetext{
${ }^{3}$ Essa entrevista está incluída numa edição do programa de televisão da RTP, que homenageou o poeta Al Berto. Não há informação da data em a entrevista foi feita. Ela está disponível online por meio do Youtube: https://www.youtube .com/watch?v=eywxQ80EdfA
} 
A obra do escritor português pode ser compreendida pela teatralização da vida e pela relação contígua entre realidade e ficção. As entrevistas auxiliam a tecer a imagem construída por Alberto Pidwell Tavares para Al Berto, o escritor que tem sob sua caneta esferográfica o corpo, isto é, fundamenta sua escrita na vida, na errância da viagem e nos sentimentos. Leonor Arfuch, no livro O espaço biográfico: dilemas da subjetividade contemporânea, desenvolve o argumento que a entrevista participa da elaboração da imagem do escritor:

\begin{abstract}
No entanto, e apesar desse empenho interativo, não é a referencialidade dos fatos ou sua adequação veriditiva o que mais conta - verdade sempre hipotética, que não está em jogo em muitas variantes da entrevista -, mas, preferencialmente, as estratégias de instauração do eu, as modalidades da autorreferência, o sentido "próprio" outorgado a esses "fatos" no devir da narração. O "momento autobiográfico" da entrevista, como toda forma em que o autor declara a si mesmo como objeto de conhecimento, apontará então para a construção de uma imagem de si, ao mesmo tempo em que tornará explícito o trabalho ontológico da autoria, que se dá sub-repticiamente, cada vez que alguém assume um texto com seu nome. (ARFUCH, 2012, p. 212)
\end{abstract}

Fernando Pinto do Amaral também tece importantes reflexões sobre o tema dos contatos estabelecidos entre obra e biografia, sugerindo o conceito de autobiothanatografia:

A respeito deste autor, julgo que estaria bem aplicado o conceito de «auto-bio-thanato-graphie» proposto por Louis Marin ( $c f r$. MORÃO, 1989, p. 183) e que esta escrita exemplifica, até pelo que de progressiva morte nela se anuncia a cada instante. [...] por enquanto, gostaria de corroborar Paula Morão quando, na esteira de Blanchot, verifica a «contaminação ficcional que a vida sofre ao ser transformada em escrita» (MORÃO, ibid., p. 176), contaminação que uma escrita como a de Al Berto obviamente espelha. Oscilando entre a «tragédie du vécu-exagéré» (MORÃO, p. 104) e a «falsidade das palavras» (MORÃO, p. 530), esta poesia mantém, de qualquer modo, a consciência de uma hipotética ou mítica autenticidade que lhe fugiria no momento da escrita: por isso «é sempre uma mentira existir/ fora daquilo que está no fundo de mim» (MORÃO, p. 517). (AMARAL, 1991, p. 121)

Isto é, as fronteiras entre experiência e escrita se relacionam, por meio de ensombramentos e superposições. As marcas das vivências dos sujeitos são articuladas por distorções, o que significa que as existências do papel e a da biografia se vinculam por meio de rastros e de fragmentos. A duplicidade que se instaura, em torno da verdade da escrita e da ficcionalização do biográfico, converte a vida em obra literária, como também faz da palavra poética realidade vivida.

Em "Morte de Rimbaud dita em voz alta no Coliseu de Lisboa a 20 de novembro de 1996”, é impossível indicar as divisas entre a vida do autor, do percurso biográfico de Rimbaud e da ficção. Esse extenso poema, que faz parte de Horto de incêndio, foi dito pelo poeta em um intervalo cronológico inferior a um ano do seu falecimento - 13 de junho de 1997. O trecho a seguir, do fragmento $I$ desse poema, declara: lábios.

a verdade é que passei a vida a fugir, de cidade em cidade, com um sussurro cortante nos e atravessei cidades e ruas sem nome, estradas, pontes que ligam uma treva a outra treva. caminho como sempre caminhei, dentro de mim - rasgando paisagens, sulcando mares, 
devorando imagens. (HI, p. 64)

“Morte de Rimbaud", sobretudo, está envolto pelos rastros biográficos, da morte e da doença, já que, na época em que foi realizado o registro oral do texto, o escritor estava enfermo em decorrência de um linfoma. Tal dado circunstancial é relevante para se analisar os escritos que compreendem esse período da vida de Al Berto. O que se pretende não é direcionar a análise da poética albertiana para o viés biográfico, mas sim não ignorar as possíveis reverberações entre a doença de Al Berto e a atmosfera de finitude em "Morte de Rimbaud" e nos demais poemas de Horto de incêndio. Isso porque as influências entre o vivido e o escrito são constituídas de maneira relacional, de forma que o discurso sobre a doença real do escritor, além de interferir na produção literária, é transformado e modificado pela obra poética. A percepção que o leitor possui sobre a enfermidade do poeta, como também a concepção que a própria crítica literária manifesta sobre os fatos biográficos de $\mathrm{Al}$ Berto estão diretamente vinculados às leituras dos livros dele. Horto de incêndio está, sobretudo, estigmatizado por ter sido o último livro do autor e por estar circunscrito no período em que já se sabia publicamente de seu estado terminal.

O apagamento dos contornos que cercam o sujeito, a vida e a literatura, portanto, estão nas palavras do eu poético de Horto de incêndio:

e a vida, afinal é como as orquídeas - reproduze-se com dificuldade.

mas estou cansado.

os olhos fecham-se com o peso das paixões desfeitas. (HI, p. 67)

O viajante, que tudo presenciou, que experienciou os outros mares e os desertos inexplorados, é invadido pela exaustão: “escavo no coração um poço de sal, para dar de beber ao / viajante que fui. / deixo o vento arrastar consigo a infindável caravana de / ilusões." (HI, p. 68). O pretérito predomina no discurso do indivíduo, que se dirige às memórias daquilo que transpassou suas retinas e se fixou no seu corpo.

O corpo se impregna da jornada de ausências e de presenças. Ele se defronta com a fuga derradeira, o destino final em "Morte de Rimbaud": “o que vejo não se pode cantar. / recomeço a fuga, a última, e nela hei de morrer de / olhos abertos, atento ao mínimo rumor, ao mais pequeno / gesto - atento à metamorfose do corpo que sempre recusou / o aborrecimento.” (HI, p. 73). A ante sua última partida, ele não se desvia da realidade que o circunda e que o atravessa, mas se depara com a impotência de contar o presenciado: "o que vejo não se pode contar". O trauma, então, se propaga em distintas direções: na forma de interdição e na recusa de ignorar os eventos que estão envolvidos no entorno - "olhos abertos, 
atento ao mínimo rumor”. Em uma entrevista, ao Jornal I, José Gil discorre sobre a loucura e sobre o trauma:

No pensamento devemos passar fronteiras de realidade. E voltar. Por vezes é difícil regressar, há quem não volte. Muitos psiquiatras heterodoxos viram existir um trauma entre certas experiências traumáticas e a descoberta. Os sonhos de Kepler, de Descartes, de Wittgenstein: após um trauma há uma pujança que pode ser fértil para a criação de um mundo que não existia. Pode existir então um trauma que seja fecundo e outro que nos transporta para o asilo. Estou convencido de que Fernando Pessoa estava constantemente em estado de trauma... (GIL, 2015, online)

O trauma em Al Berto está relacionado à criação dessa dimensão que não existe, o corpo de papel - "o exíguo corpo das palavras" (SGM in MD, p. 313). A "alma esburacada por uma agonia tamanho deste mar" (HI, p. 40) encontra, mesmo que na precariedade das palavras, a dimensão em que inventará o outro país, o outro cosmos. Da folha de papel, precipitam-se os corpos diversos de Al Berto:

\author{
mas existe sempre um qualquer lume eterno \\ um coração feliz à esquina dos sonhos \\ surge agora o deserto que toda a noite procurei \\ está em cima desta mesa de trabalho no meio das palavras \\ donde nascem indecifráveis sinais...irrompe \\ o movimento doutro corpo colado ao aparo da caneta \\ desprende-se da folha de papel agride-me e foge \\ deixando-me as mãos tolhidas num fio de tinta. (SGM in MD, p. 279).
}

Nesse trecho, o corpo que escreve e aquele que surge do papel se fundem, diluindo os vestígios que diferenciam realidade e escrita. $\mathrm{O}$ trauma como outras questões da poética do português conduz para o agenciamento de posições aparentemente incompatíveis, visto que além de essa poesia apontar a escrita como criação - "quando escrevo mar / o mar todo entra pela janela" (SGM in MD, p. 296) - ela também indica a impossibilidade de escrever sobre as dores que circundam o indivíduo.

O deserto e o silêncio mostram-se a morada última, em que o eu poético deseja habitar, em que "as mãos redescobriram o silêncio inesgotável da escrita / praticam esse ofício muito antigo / de na imobilidade da fala tudo desejarem" (SGM in MD p. 274). Apesar de desejar a "imobilidade da fala", a ausência do outro se impõe: "escrevo / a crueldade das palavras que te cantam / tento acender outras imagens devoradas pelo tempo / mas estou confuso e definitivamente só." (SGM in MD, p. 291). A melancolia, portanto, nessa poesia, pode configurar-se pela perspectiva contemplativa, em que se deseja a viagem solitária por ilhas e pelo oceano inóspito - "espero o cortante sal-gema das ilhas... a ilusão / de me prolongar na secreta noite dos peixes / adormeço / para que estes dias aconteçam mais lentos / nas proximidade inalteráveis deste mar" (SGM in MD, p. 270) - e pode, também, apresentar a dor, tomada de angústia e de desespero: 
e mais nada se move na centrifugação
dos segundos - tudo nos falta
nem a vida nem o que dela resta nos consola
a ausência fulgura na aurora das manhãs
e com o rosto ainda sujo de sono ouvimos
o rumor do corpo a encher-se de mágoa. (HI, p. 37)

Em Saturno e a melancolia, ao examinar a melancolia poética no período pósmedieval, os autores identificam essa duplicidade desse discurso:

Lo que aquí apunta es la melancolía específicamente "poética" de los modernos: un sentimiento de doble filo que constantemente provee a su propio sustento, en el que el alma disfruta de su aislamiento, pero por ese mismo placer vuelve a tomar mayor conciencia de su soledad, "la alegría en el dolor", "la luctuosa alegría" o "el triste lujo del pesar", por decirlo en palabras de sucesores de Milton. Esta melancolía moderna es esencialmente una conciencia de uno mismo intensificada, puesto que el yo es el eje en torno al cual gira la esfera de la alegría y del dolor; y tiene también una relación íntima con la música, que ahora se pone al servicio de las emociones subjetivas. ${ }^{4}$ (KLIBANSKY et al., 1991, p. 229230)

No eu da poesia albertiana não há um eu estruturado que simplesmente coordena os sentimentos e as emoções, há nele uma determinação perceptível para a desconstrução de si. A construção da subjetividade nessa poética se insere nos parâmetros do eu que desestabiliza as certezas sobre sua identidade. Isso porque a intimidade evidenciada é constantemente sobreposta e reorganizada pelo corpo: do outro, da palavra, da paisagem, da cidade, de Rimbaud, de Rousseau, da casa e do viajante. A multiplicidade de subjetividades que transitam nos poemas, em vez de esclarecer e iluminar os contornos do sujeito, faz o efeito contrário ao deturpá-los e borrá-los. $\mathrm{O}$ eu, como eixo das emoções, mencionado em Saturno e a melancolia (1991), pode auxiliar na compreensão da melancolia em Al Berto, na medida em que a subjetividade adquire importância no pensamento sobre o discurso melancólico. Contudo, não é possível aderir à imagem do "eu como eixo" para pensar esse "estado de ânimo". No cenário de descentramento do eu, da poética do português, é mais adequado pensar a subjetividade como um espelho fraturado produtor de reflexos disformes e desfocados. Acerca dessa questão do eu na poesia do escritor português, Sasaki afirma:

Percebe-se daí a ambivalência da afirmação/ocultação do sujeito, que simultaneamente reclama uma posição enunciativa biográfica - em seus atos de identificação e protocolos de leitura -, ao mesmo tempo em que, forçosamente, coloca sua poesia em terreno instável, no qual a expressão íntima, paradoxalmente, não joga luz sobre o sujeito poético, mas o ensombra e o descentra. (SASAKI, 2013, p.

\footnotetext{
${ }^{4} \mathrm{O}$ que aqui se evidencia é a melancolia especificamente "poética" dos modernos: um sentimento de duplicidade que constantemente provê seu próprio sustento, em que a alma desfruta do isolamento, mas por esse mesmo prazer toma maior consciência de sua solidão, "a alegria na dor", "a lutuosa alegria" ou "o triste luxo do pesar", por dizê-lo nas palavras dos sucessores de Milton. Esta melancolia moderna é essencialmente uma consciência de um si mesmo intensificada, já que o eu é o eixo em torno do qual gira a esfera da alegria e da dor; e tem também relação íntima com a música, que agora se coloca ao serviço das emoções subjetivas. (Tradução da autora).
} 
160)

A melancolia, por sua vez, da mesma maneira se insere no âmbito da instabilidade. $O$ sujeito melancólico desestabiliza as angústias e as preocupações com o mundo, por meio da relativização da memória - "começou a falhar-me a memória / já não sei se esta cabeça de pano existe ou ainda existirá" (SGM in MD, p. 321) - e da desconfiança em relação à completude e à integridade dele: "mesmo assim sofro de insónia - imito o noitibó / o bêbado louco / gesticulo como aquele que já não sou e / outro não serei” (HI, p. 35). A melancolia, nessa poesia, devassa as tristezas e a dor, desnudando as fragilidades do "tu" e do "si".

A tal respeito, é interessante mencionar o que diz Rosa Maria Martelo:

Do ponto de vista da experiência do sujeito, daquele que por vezes a si mesmo se designa pelo nome de Al Berto, é ainda caminhar da euforia da possibilidade de encontro, com o outro e consigo mesmo, para uma solitária melancolia, cada vez mais envolvente e desamparada (MARTELO, 2001, p. 44).

No trecho a seguir, a segunda morada de silêncio, o corpo, é maculada pela escrita, que contraria a vontade do eu poético de afastamento e de exílio. Se a primeira morada é a escrita,

a segunda irrompe do corpo movendo-se por trás das palavras extensas praias vazias onde o mar nunca chegou deserto onde os dedos murmuram o último crime escrever-te continuamente... areia e mais areia construindo no sangue altíssimas paredes de nada (SGM in MD, p. 256)

Estabelece-se entre a tinta e o corpo a relação conflituosa de isolamentocomunicabilidade. Entretanto, "as palavras", em vez de contribuir para estreitar as possibilidades de diálogo entre esse dois - corpo e poesia -, intensificam o isolamento do indivíduo: "extensas praias vazias onde o mar nunca chegou" e "deserto onde os dedos murmuram o último crime". A escrita é, em Horto de incêndio e em Salsugem, uma questão esfíngica por ser ao mesmo tempo: a maneira de sobrevivência do indivíduo, o corpo que ele habita a fim de entrar em contato com as lembranças e com o corpo-amante - "o enigma de escrever para me manter vivo / a memória desaguando a pouco e pouco no esquecimento perfeito / para que nada sobreviva fora deste corpo viandante" (SGM in MD, p. 279); e o espaço de descrença e de desesperança que reforça as distâncias que separam o sujeito do outro e do passado - “escreves exactamente isso: o horror dos dias / secou contra os dentes e rouco / dobrado para dentro do teu próprio pensamento / ferido / atravessas as sílabas diáfanas do poema" (HI, p. 22). O dilema da palavra não é resolvido, ele é dramatizado e intensificado, o que resulta na poética que situa o sujeito diante da angústia. O silêncio e as imagens estão constantemente no limiar do abismo, negociando a necessidade de expressão, 
de tinta e de papel com a procura pelo deserto e pela ausência da palavra. O eu lírico se depara com a precariedade da linguagem e com a garantia - mesmo que problemática - de a escrita percorrer as memórias, as cidades, o corpo e o outro:

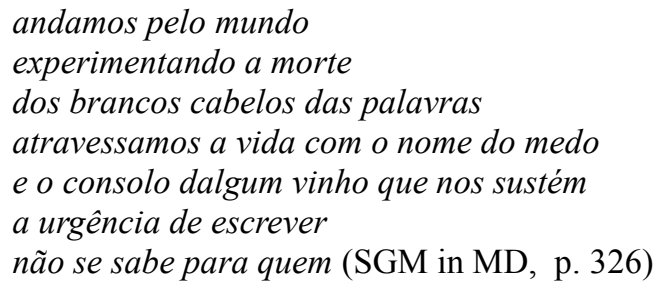

O corpo-poesia, então, é reduto da melancolia nos sentidos explicitados em Saturno e a melancolia (1991): o estado contemplativo gerado pela solidão; e a consciência das implicações negativas do isolamento. Nos versos, "escrever-te continuamente... areia e mais areia / construindo no sangue altíssimas paredes de nada", a inutilidade da escrita amplifica os obstáculos que se interpõem entre o "eu" e o "tu".

O corpo do outro e o corpo do nômade estão situados no espaço da memória e da escrita. O eu poético, então, vacila entre a descrença na palavra - "não se sabe para quem" escrever - e a expectativa de encontrar o refúgio nos "gatafunhos" da existência de papel - "a urgência de escrever". A memória, também envolta pela tensão dos contrários, por sua vez está cercada pela insistência em recorrer às lembranças, à fotografia, à juventude e à imagem do amor do passado e pela necessidade do esquecimento e do silenciamento dos vestígios de memória:

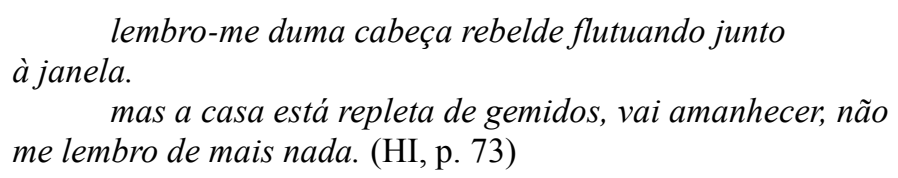

No artigo "Al Berto, a escrita, o corpo, a vida", Sandro Ornellas explicita as características da memória nesse escritor:

\begin{abstract}
Não uma memória criadora de formas centralizadoras, fantasmáticas e divinizantes de existência, a domesticar o corpo. Sua memória também pulsa, vibra, sangra, treme, vive e morre, pois não é apenas representação, mas uma memória feita de carne, feita de dor e prazer físicos. A memória para o poeta é principalmente a sua espacialização, sua inscrição flutuante e instável, por onde o corpo pode navegar à cata novos fragmentos para a sua montagem (...) (ORNELLAS, 2008, p. 115)
\end{abstract}

Acerca do interlocutor, é interessante compreender os sentidos que o circundam. $\mathrm{O}$ "tu" - o outro - na poesia albertiana é convocado pelo eu poético como um ouvinte, exercendo a função quase acessória, ou como partícipe e companheiro das aflições e errâncias do sujeito. Ao analisar mais atentamente, o "tu", em Al Berto, observar-se que esse 
interlocutor pode não ser o outro:

\begin{abstract}
procuras ávido aquilo que o mar não devorou e passas a língua na cola dos selos lambidos por assassinos - e a tua mão segurando a faca cujo gume possui a fatalidade do sangue contaminado dos amantes ocasionais - nada a fazer
\end{abstract}

irás sozinho vida a dentro

os braços estendidos como se entrasses na água (HI, p. 17)

$\mathrm{O}$ eu poético prediz as ações daquele que não é necessariamente outro sujeito. $\mathrm{O}$ poema indica o direcionamento do discurso para o próprio locutor, constituindo mais uma estratégia retórica, de esvaziamento do efeito de comunicabilidade do "tu", do que uma tentativa do eu lírico de interlocução consigo. Produz-se, com isso, o efeito de objetificação da segunda pessoa convocada pelo texto. O procedimento conduz para o esgotamento e para a perda de sentido do diálogo com o outro, e indica a impossibilidade de o sujeito estabelecer conciliação com sua própria solidão e com seu desassossego. O interlocutor é imagem especular do eu lírico, o duplo com quem ele tenta efetuar a revisão de seus atos e de sua vida. Mesmo quando o receptor do eu poético se materializa, isto é, concretiza-se no texto, o diálogo com o "tu" é perpassado pelo pesar diante da ausência e da inviabilidade de encontro com o amante, sendo a memória e a escrita as formas exclusivas de fazer o amado presente:

paguei o vinho o pão e o queijo
levantei-me
tu cortaste-me a fuga vagarosamente preparada
pediste-me um cigarro
na outra página estávamos rindo
estendidos no pobre embarcadouro de madeira
planeávamos atravessar a noite mágica do rio
a página seguinte está em branco
mas lembro-me que te agarrei as mãos e disse:
todos os cigarros do mundo são para ti (SGM in MD, p. 295)
O sujeito melancólico, em Salsugem e em Horto de incêndio, está instituído, sobretudo, na falha, na fissura, restando a ele a mutilação, o inacabado, o imperfeito. Em Filosofia cinza: melancolia e o corpo nas dobras da escrita, Márcia Tiburi concebe o sujeito melancólico a partir da falta, da lacuna:

O sujeito deixa falar seu vazio e constrói o mundo a partir do saber sobre sua solidão, sobre seu nada ser - ele se compara e se mede na eterna autoafirmação de sua miséria, de seu não saber, de sua ignorância - e a carrega para reinstaurá-la no lugar metafísico, na fundação do sujeito, para dar uma cor ao eu, a cor negra do abismo escuro onde cada um perdeu a si mesmo. O eu melancólico é o fantasma. Persegue-lhe o dever-ser dizendo-lhe que a ordem do mundo é outra e ele um estrangeiro desse mundo dos vivos. O melancólico é o túmulo flutuante de si mesmo. O "si mesmo" é esse desaparecido, essa cogito sem rumo, navegador eterno sobre o mar nonsense, espécie de morto vivo que carrega o lema da 
existência como a navegação precisa: “existo” é seu réquiem. (TIBURI, 2004, p. 54)

A negação e a fissura se radicam em Salsugem e em Horto de incêndio, inviabilizando qualquer tentativa de vínculo. O sujeito na palavra albertiana é o estrangeiro comentado por Tiburi (2004), indivíduo que constrói sua existência a partir do vazio:

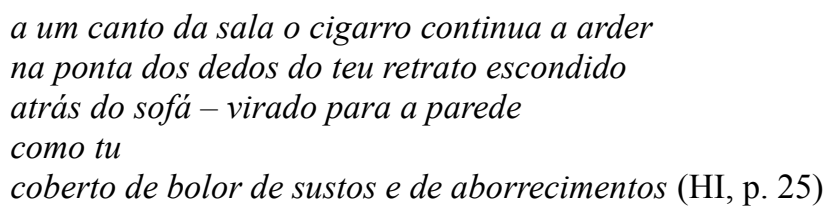

O sujeito esfacelado sabe que não é crível o encontro com a totalidade e com a integridade de si. A jornada do sujeito albertiano segue o curso fúnebre, a marcha para o fim, incendiando e destruindo as certezas e a crença de totalidade, seja do corpo-texto, seja do próprio corpo ou do corpo alheio. Diante disso, é possível pensar a melancolia, nos dois livros, como o mecanismo pelo qual essa poética se relaciona com o mundo. O discurso melancólico é o mediador do sujeito em relação à memória e ao corpo, a partir da perspectiva da perda e da morbidade. Em outra estrofe do mesmo poema, o "lodo" e as "sílabas preciosas" são imagens equiparadas pelo eu poético, compondo um cenário de decomposição e de solidão:

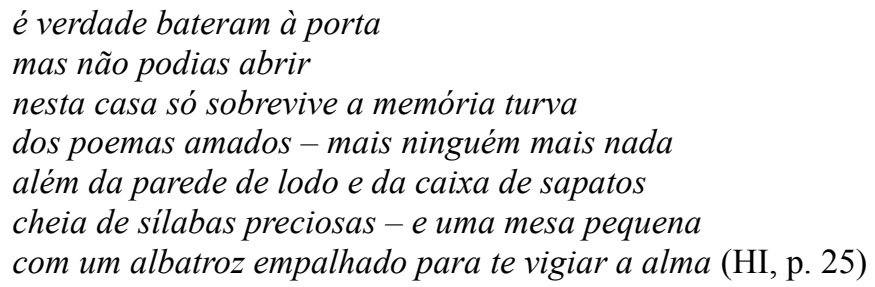

A denominação autobiothanatografia, sugerida por Amaral (1991) como maneira de compreender a produção do poeta a partir do direcionamento à morte, é uma forma interessante de se analisar essa obra, pois conduz às temáticas da escrita do eu e do aniquilamento: "mas a morte quando se aproxima, é uma coisa simples... vem comer à mão a cinza melodiosa dos dias" (HI, p. 69).

A partir da "lente" da melancolia, são percebidos o corpo e a memória. A memória é imprecisa e o indivíduo está sozinho, inabilitado de estabelecer contato com o outro. Memória/esquecimento/escrita estão implicados na constituição do corpo fracionado e múltiplo. Esse corpo, inscrito na noite, na fotografia, no papel, se compromete com a travessia, com o medo e com a morte: 
o ácido das noites em sépia

no vidro das montras pressentimos a fuga

o desabar da cidade o peso da chuva... sempre

que o diálogo existe entre a sensibilidade do corpo

e do filme... as mãos repetem os gestos

as palavras desfazem-se no lusco-fusco surge o medo

estas pedras fascinadas pelos neóns donde se solta a fera

que nos devassa os umbrais dos dias morrendo (SGM in MD, p. 322)

O desejo e o desespero se instalam na poética albertiana, na medida em que há uma tentativa de alcançar o outro e de estabelecer uma ordem às coisas: "o tempo não se gastou / passei estes anos a colocar as coisas / nos seus devidos lugares" (SGM in MD, p. 293). O que se sabe é que esse desejo é fadado ao fracasso desde sua origem, já que o sujeito está ciente de que seus anseios não podem ser atingidos:

eu vou continuar aqui
arrumando as pedras os fogos o cuspo os astros as veias
a florida água das paixóes
daquela memória todos os actos
onde a ausência do corpo-amante adquiriu a ternura do barro
e a vida esquecida dalguma cassiopeia (SGM in MD, p. 271)
O desejo de ordenar e de organizar a paisagem, o cosmos, o corpo e os sentimentos procede da ausência. A escrita e a memória são as possibilidades de restituir a presença do corpo-amante. Mesmo afirmando "eu vou continuar aqui / arrumando as pedras os fogos os astros as veias", na poética do português, é onipresente a consciência do fracasso de sua empreitada:

arrasto comigo o cheiro amargo da memória mascaro os dias com palavras cujo significado perdi mas nenhuma felicidade vem alojar-se no coração (SGM in MD, p. 334)

A memória amarga e as palavras sem significado estão envoltas pela negatividade. A felicidade, então, não pode ser alcançada pelos caminhos das lembranças e da escrita, o trajeto para ela está interdito. A melancolia é tanto o intermediário do sujeito com o entorno, a forma que ele compreende o mundo, como aquilo que está resguardado para ele, seu destino final.

Agamben (2007), ao deter-se sobre as origens do que se entende como sendo o comportamento do acidioso, analisa a aflição que acometia os monges na Idade Média, sob a perspectiva do paradoxo da acídia:

É assim que a ambígua polaridade negativa da acídia se torna o fermento dialético capaz de transformar a privação em posse. Já que o seu desejo continua preso àquilo que se tornou inacessível, a acídia não constitui apenas uma fuga de..., mas também uma fuga para..., que se comunica com seu objeto sob a forma da negação e da carência. Assim como acontece com as figuras ilusórias que podem ser interpretadas ora de um, ora de outro modo, assim também cada traço seu desenha, na sua concavidade, 
a plenitude daquilo de que se afasta, enquanto cada gesto realizado por ela na sua fuga testifica a manutenção do vínculo que a liga a ele. (AGAMBEN, 2007, p. 32)

A "fuga para" delineia a inconciliável contradição a que o sujeito está submetido. Nesse cenário de afastamento e de aproximação do objeto, atrelar a preguiça ao comportamento do acidioso deturpa o desespero e a agonia experimentados por ele. A falta de ação e a morosidade ligada à acídia se devem à paralisia causada pelo medo aterrador que acomete o indivíduo. Agamben evoca a iconografia medieval para pensar sobre esse fenômeno:

Esse desesperado aprofundar-se no abismo que se abre entre o desejo e o seu inapreensível objeto foi plasmado pela iconografia medieval no tipo de acídia, representado como uma mulher que desoladamente deixa cair por terra o olhar e solta a cabeça sustentada pela mão, ou então como um burguês ou um religioso que confia o próprio desconforto ao travesseiro que o diabo lhe oferece. O que a intenção mnemotécnica da Idade Média oferecia para a edificação de quem contemplava não era uma representação naturalista do "sono culpado" do preguiçoso, mas o gesto exemplar de deixar cair a cabeça e o olhar como emblema da desesperada paralisia do ânimo diante da sua situação sem saída. (AGAMBEN, 2007, p. 30-31)

A inexistência de solução para esse impasse situa o indivíduo no ambiente de inquietude. É possível compreender Salsugem e Horto de incêndio sob o aspecto da acídia, contudo, é necessário efetuar algumas alterações na maneira de se entender esse comportamento na poesia do português. "Abandonar a aldeia o lugar a casa o corpo / a escrita e todas as paisagens / viajar escondido no comboio-correio da noite" (SGM in MD, p. 265): a poética albertiana ressignifica a clausura monástica por meio da viagem errante. O deserto, o mar, o deslocamento sem rumo definido são maneiras de isolamento e de reclusão. A inviabilidade de concretizar o desejo, de presentificar o corpo-amante e de ordenar os objetos e a realidade fazem o sujeito em Salsugem e Horto de incêndio refugiar-se nesses ermos. Por isso, o mar-deserto percorrido pelo eu poético é o espaço em que os corpos se confrontam com o silêncio e com a solidão. $\mathrm{O}$ mar é a habitação daqueles que encontram, na imensidão das águas salgadas, o isolamento.

A fuga-viagem está imbricada nessa poética, ela constitui-se pela busca do indivíduo por seus desertos.

as luzes do cais revelam-me corpos fugidios penumbra donde se escapavam ditos obscenos gemidos agudos sibilantes risos que despertavam em mim a vontade sempre urgente de partir (SGM in MD, p. 302)

A fuga última, a de Al Berto, a de Rimbaud e a do eu poético, está na dimensão da palavra e da imagem, as quais encaminham o olhar pelas incongruências, pelos desencontros e pelas impossibilidades da realidade: "o que dissemos perdeu o sabor e o sentido. / harrar, 
aden, lisboa, este silêncio... capaz de ordenar e / desordenar o mundo. o canto sublime das miragens.” (HI, p. 66). Harrar e Aden, as cidades que o itinerante Rimbaud percorreu durante a época em que interrompeu sua produção literária e iniciou a vida de comerciante coincidem com a Lisboa de Al Berto

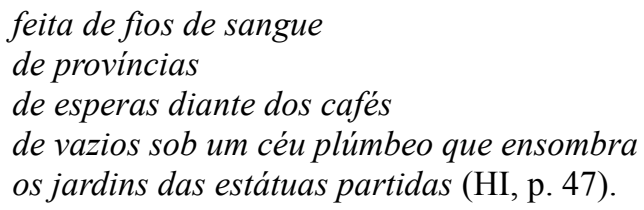

Essa poética persiste com a obsessão na ideia de fuga, que se caracteriza pela maneira possível de sobreviver: "não tenho mais nada a dizer. os poemas morreram. / fugir tornou-se uma obsessão, ou então é a melhor ma- / neira de encenar o desespero / bebi águas inquinadas. / vi o corpo suspenso no rebordo dos poços, / o coração batendo descontrolado." (HI, p. 69). Vida e desespero se confundem materializando o medo e a melancolia no trajeto fúnebre do sujeito. E, nesse itinerário em que o eu poético passou "a vida a fugir, de cidade em cidade, com um / sussurro cortante nos lábios", confundem-se em Horto de incêndio a existência errante de Rimbaud, a vida de viajante de Alberto Tavares pela Europa e a do eu poético que faz uma revisão dos seus trajetos pelas cidades, ruas, estradas, silêncios, presenças e pontes por onde caminhou.

Na poesia de Al Berto, o corpo se situa no âmbito do performático, da subjetivação, da homoafetividade, do outro, da alteridade, da fragmentação, da morbidade. De acordo com Ornellas,

\begin{abstract}
Nos textos, as viagens se fazem, as leituras avultam, os amores de realizam, as notas se registram, os inventários assomam, as cópias - implícitas ou explícitas - ensaiam formas diferentes e fabricam sua postura, o gesto, a técnica, o corpo próprio - estrangeiro, híbrido, mestiço, andrógino, hermafrodita, monstruoso pela sua desmedida. O que há - de fato - é um movimento de ruptura com as fronteiras de todas as espécies, ruptura com a própria ideia de que o texto poético seja sempre um comentário (crítico) sobre a vida - e não uma forma de experiência da vida na sua dimensão mais concreta e real. Al Berto soube se forjar um especialista extremamente arguto e competente na arte de elaborar formas de sensibilidades e formas sensíveis - seu texto é a realização, a formalização dessas vontades do seu corpo; bem distante das modalidades moralizantes de se pensar, se ler e se interpretar o gesto da criação. (ORNELLAS, 2008, p. 98-99)
\end{abstract}

O narcísico, o biográfico, o sujeito, a ficção e o corpo atuam, portanto, a partir de presenças e ausências. É dessa forma que essa poesia incendiária, como diz Melo e Castro, constrói semas de emoção e sentimento - emossemas:

Al Berto dá-nos a recuperação do discurso através de um conhecimento dos elementos de que esse discurso se pode construir, sem discursividade, isto é, sem a autocomplacência de quem se ouve e gosta de se ouvir, no que julga que diz. Esta delicada operação semântica só é possível por uma permanente oscilação entre o abandono e a vigilância, a que a negatividade dá um sabor amargo da experiência (CASTRO, 1989, p. 104). 
Como aponta Eduardo Prado Coelho ao analisar Uma existência de papel, e que pode ser estendido para a análise de Salsugem e Horto de Incêndio, o itinerário poético de Al Berto direciona-se para a morte:

Para sermos correctos: é um livro em que tudo se põe a morrer. Dois versos dizem isto com admirável concisão: "quando aqui não estás / o que nos rodeou põe-se a morrer". O mais interessante deste texto de Al Berto é o modo como ele vai trançando o frágil rendilhado negro desta impregnação da morte. Ela começa na fotografia que acompanha o volume e reduz a imagem da mão ao corte sombreado. Ela passa pelo título, onde se diz o modo como a existência se vai desumunindo e adelgaçando até ficar reduzida à leveza evanescente de um papel (PRADO COELHO, 1988, p. 156).

O caminho para a morte vai se desenvolvendo pelo abismamento e até a redução ao desaparecimento e destruição do corpo e da escrita dos versos finais de cada livro onde: “talvez encontres estes papéis escritos / no recanto mais esquecido da noite... talvez / descubras o vazio onde o corpo desgasto esperou / vou destruir todas as imagens onde me reconheço / e passar o resto da vida assobiando ao medo" (SGM in MD, p. 317); e "o que vejo não se pode cantar. / caminho com os braços levantados, e com a ponta dos / dedos acendo o firmamento da alma. / espero que o vento passe... escuro, lento. então entrarei nele, cintilante, leve... e desapareço.” (HI, p. 73)

Isto é, a melancolia é a forma encontrada pelo sujeito de estabelecer a sua leitura do mundo e de relacionar-se com ele. Amaral reflete que:

o mundo de Al Berto pode considerar-se, deste modo, um dos mais melancólicos da nossa poesia recente. Seu tem sido o culto dessa "dificil arte da melancolia" (LR), essa sensação psico-afectiva herdeira da acedia medieval e em que se conjugam, saturnianamente e numa indefinível mistura, o torpor, a nostalgia e o tédio. (AMARAL, 1991, p. 125)

Ao erguer "moradas de silêncios", "edifícios de nada", paisagens existentes somente numa fotografia, amores proscritos e viagens sem rumo, a escrita de "sal" e de "incêndio" instaura o discurso que renega as conciliações. Eleger, como percurso, a fissura, para aproximar-se da melancolia albertiana, permite compreender que ela parece derivar do desassossego do sujeito diante da sua incapacidade de compreender as vicissitudes da realidade.

A poética albertiana estabelece sua palavra melancólica no intervalo, isto é, numa realidade terceira que se situa entre a vida e a ficção. As várias camadas que se interpõem entre o real e o escrito, nos poemas de Salsugem e de Horto de incêndio, fazem que a melancolia adquira a perspectiva especular, de distorcer aquilo que está sob suas "lentes”: “o mundo que te rodeou continua inaudível e perdido / apodrece nas fotografias arrumadas dentro da gaveta / debaixo da roupa engomada" (SGM in MD, p. 334). Ela é uma mediadora 
entre o sujeito e o mundo, e, além disso, é a agenciadora que se interpõe entre o sujeito e a escrita.

Al Berto tem sua poesia inscrita nos liames da discursividade e da referencialidade. A volta aos "relatos simples” é uma das características indicadas por Rosa Maria Martelo (2003) na poética de Al Berto. A linguagem, então, reconstrói essa discursividade, de maneira que ela é deslocada da instância do real. Melo e Castro comenta a negatividade e os seus vínculos com a dita retomada do real presente na poesia do português:

o niilismo, a abjeção, a recusa, a solidão são assim assumidos como valores escriturais, propondo um novo sentido do texto poético que consiste na reconstrução dum discurso deliberadamente discursivo, descritivo e referencial, criando uma distância táctica entre aquilo que se diz, se descreve ou se refere e o modo como efectivamente constrói o discurso. (CASTRO, 1989, p. 105)

Martelo percebe esse movimento duplo e aparentemente contraditório da poesia a partir da década de 70, explicando que:

É por esse motivo, provavelmente, que o lirismo figurativo é apenas um dos desenvolvimentos da poesia do último quartel do século XX. O lirismo abstractizante e impessoal tem todas as condições para permanecer, embora seja particularmente visível (e interessante) a tendência para fundir as duas possibilidades numa espécie de sincretismo que, ao mesmo tempo, recupera a tradição da Modernidade (pelo fato de reutilizar/prolongar) e a subverte, por poder combiná-la com um registro muito mais figurativo e susceptível de produzir um efeito de realismo. Nas décadas de 40 e 50, quando o efeito de realismo era obtido por referência a uma versão de mundo ontologicamente forte (o marxismo, por exemplo), a sua presença facilmente implicava que a tradição da Modernidade fosse colocada "sob rasura". Agora ambos parecem poder conviver sem grandes dificuldades (MARTELO, 2003, p. 101)

O desassossego presente em Al Berto, portanto, tem sua referencialidade comprometida pela palavra que estilhaça e desestrutura as certezas sobre o sujeito e sobre a vida. Em Salsugem, o hermetismo se entrelaça com a descrição de ações e de cenas, a exemplo de: "hortelã bravia esmagada contra o rosto / seiva morna sobre o ventre emaranhado nas trepadeiras / secas latas de conserva detritos de comida / um fio de azeite escorre da boca" (SGM in MD, p. 259). Em Horto de incêndio, também, é possível identificar a mescla entre o corriqueiro, o identificável e o esfacelamento da palavra e do sujeito: "não saberás nunca da tua metamorfose / em pantera aérea - vou proibir que te passeies por cima dos sentimentos e dos móveis" (HI, p. 20).

A dificuldade de acercar-se das experiências demonstra que a poética de Al Berto está atravessada pelo trauma. A perda da coesão da linguagem aponta para a complexidade de o sujeito aproximar-se dos sentimentos, que são de difícil verbalização. As imagens enigmáticas estão ligadas ao onírico que se infiltra em Salsugem e em Horto de incêndio. Amaral, sobre a palavra que se vincula à problemática do eu poético/tu de relacionar-se com o entorno, explica: "O recurso do onírico traduz, como sempre, uma insuficiência do real, um profundo e 
enraizado mal-estar que se infiltra no quotidiano e leva o eu a desejar fugir-lhe a qualquer preço" (AMARAL, 1991, p. 125).

Mesmo estando envoltos nesse mal-estar, a melancolia que percorre Salsugem e Horto de incêndio não somente nega a vida. A negatividade e a descrença carregam, de fato, uma afirmação do vivido e do que ainda se pode experienciar. $\mathrm{O}$ discurso que ressalta e evidencia o desassossego da existência se avizinha daquilo que aparentemente rechaça: a vida. O sujeito que lamenta suas perdas também viveu o amor, os excessos, as viagens, mesmo que de maneira incompleta e fragmentária. O corpo estendido no quarto de "zinabre" e de "álcool" é o mesmo que tem o gosto pela vertigem da noite e pelas viagens. O sentir, portanto, é primordial na poética albertiana, o aproximando, não necessariamente da positividade, mas de alguma forma da pulsação do vivido. A esterilidade e desertificação desejadas pelo sujeito derivam do vigor e da potência da noite e da existência. Prado Coelho, ao analisar o trabalho de José Gil sobre a poesia de Fernando Pessoa afirma que o filósofo contraria a tendência de imputar somente o niilismo a essa poética. Citando as palavras de Gil, o crítico comenta: "Em terceiro lugar, José Gil vai inverter radicalmente o pendor niilista das leituras pessoanas. $\mathrm{O}$ programa experimental de Pessoa é 'sentir tudo e de todas as maneiras' e isso só pode ser lido como uma extraordinária afirmação da vida" (PRADO COELHO, 1988, p. 70). O comentário poderia ser feito igualmente a respeito da poesia albertiana, em que sob o véu da melancolia pulsa uma ânsia vital e sente "tudo e de todas as maneiras".

Se a poesia for considerada, uma arte que se erige da crise, a sensibilidade poética está intrinsecamente vinculada à dificuldade e à perturbação. Aqui se pode mencionar, novamente, a entrevista de Al Berto na qual declara que, para ele, a escrita nasce de uma perturbação. A vida e a morte não são oxímoros, mas sim perspectivas que se complementam e se relacionam. Em Salsugem e em Horto de incêndio viver é percorrer os labirintos da morte, mas também o aniquilamento e a morte vislumbram a vida e a recriação.

No quadro traçado de melancolia e desespero, assoma ao ambiente crepuscular dessa poesia, o desejo e o indício fugaz da "morada eterna". Ao realizar suas jornadas, o eu poético espera deparar-se com a ilha onde ele possa se "prolongar na secreta noite dos peixes". O sujeito demonstra, no léxico povoado por estrelas, mares, outras ilhas e sonhos que, na verdade, seu ceticismo está prenhe de vida. Não se trata de uma simples afirmação da realidade e do sentimento de positividade, mas sim da consciência dos vícios e das degenerações da realidade, que necessita ser suplantada por outra, assim como o corpo cindido e despedaçado abre caminho para a concepção de outros corpos. E a escrita, por sua vez, mesmo que de maneira corrompida, propicia ao sujeito a construção de ilusões e de 
dimensões: quando escrevo mar / o mar todo entra pela janela" (SGM in HI, p. 296).

O esvaziamento do sujeito até sua nadificação aponta para a possibilidade de que dele surja outra noite, outro corpo e território. Eduardo Prado Coelho, no ensaio intitulado $\mathrm{Al}$ Berto: começar a morrer, referente à crítica de Uma existência de papel, pondera sobre o vazio que tem a potência de gerar e de criar:

Mas esse retraimento que esvazia o mundo de toda a sua realidade deixa com este vazio a disponibilidade para o desconhecido. Porque "onde termina o corpo deve começar outro". Porque o verso sustenta uma inevitável interrogação: "no fim deste século / acordarão homens no outro lado da manhã?” (PRADO COELHO, 1988, p. 157)

Assim, a melancolia sublimada na poesia de Al Berto, acompanhada de todo o léxico negativo que suscita está estritamente fincada na vida e no sentir, comprometida com o sentido e a pulsação do viver; e ao mesmo tempo separada deles, produzindo um feixe de sentimentos que centram e descentram, ordenam e desorganizam as palavras, o mundo e as pessoas. Essa melancolia se desdobra no papel e desenvolve todas as possibilidades de desilusão, de morte e de decadência, para que na casa embolorada e habitada por fantasmas possa ser possível o surgimento de outras dimensões.

\section{REFERÊNCIAS}

AGAMBEN, Giorgio. Estâncias: a palavra e o fantasma na cultura ocidental. Tradução: Selvino José Assman. Belo Horizonte: UFMG, 2007.

O que é o contemporâneo e outros ensaios. Tradução: Vinicius Nicastro Honesko.

Chapecó: Argos, 2009.

AL BERTO. Horto de incêndio. Lisboa: Assírio \& Alvim, 2010.

. O medo: trabalho poético 1974-1997. Lisboa: Assírio \& Alvim, 2009.

. Salsugem. In: . O medo: documenta poética. Lisboa: Assírio \& Alvim, 2009.

.[Entrevista]. Rádio Televisão Portugal. Disponível em: https://www.youtube.com

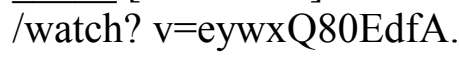

AMARAL, Fernando Pinto do. Mosaico fluido: modernidade e pós modernidade na poesia portuguesa mais recente (autores revelados na década de 70). Lisboa: Assírio \& Alvim, 1991;

ARFUCH, Leonor. O espaço biográfico: dilemas da subjetividade contemporânea. Rio de Janeiro: EdUerj, 2010.

BENJAMIN, Walter. Origem do drama trágico alemão. Tradução: João Barrento. Belo Horizonte: Autêntica, 2011. 
CASTRO. E. M. Recensão crítica a 'O Medo', de Al Berto; 'Lunário', de Al Berto. Revista Colóquio/Letras, n.112, Recensões Críticas, nov. 1989.

CATTANEO, Carlos Vittorio. Recensão crítica a 'Salsugem', de Al Berto. Revista Colóquio/Letras, n. 91, Recensões críticas, maio, 1986.

GIL, José. Entrevista. 13/03/2015. Disponível em: http://www.ionline.pt/263146\#close. Acesso em 15 de abril de 2015.

GINZBURG, Jaime. Literatura brasileira: autoritarismo, violência, melancolia. In: Crítica em tempos de violência. São Paulo: Editora da Universidade de São Paulo; FAPESP, 2012.

MARTELO, Rosa Maria. Corpo, velocidade e dissolução: de Herberto Helder a Al Berto. Cadernos de Literatura Comparada, n. 3-4, p. 42-58, dez. 2001.

. "Modernidade e senso comum: o lirismo nos finais do século XX". Cadernos de Literatura Comparada, n. 8-9, p. 89-104, dez. 2003.

MARTINS, Manuel Frias. 10 anos de poesia em Portugal. Lisboa: Caminho, 1986.

ORNELLAS, Sandro. Al Berto, a escrita, o corpo, a vida. Revista Brasileira de Literatura Comparada, n.12, p.91-119, 2008.

PRADO COELHO, Eduardo. Al Berto: começar a morrer. In: . A noite do mundo. Lisboa: Imprensa Nacional, 1988.

José Gil: um terceiro paradigma nos estudos pessoanos. In: . A noite do mundo. Lisboa: Imprensa Nacional, 1988.

SASAKI, Leonardo de Barros. A intimidade penumbrosa: nota sobre a escrita de si em Al Berto. Revista do Núcleo de Estudos de Literatura Portuguesa e Africana da UFF, v. 5, n. 11, nov. 2013.

TIBURI, Márcia. Filosofia cinza: a melancolia e o corpo nas dobras da escrita. Porto Alegre: Escritos Editora, 2004. 